\title{
THE COMPLEX SCHEME OF PREVENTION OF GASTROINTESTINAL DISEASES OF PIGLETS IN FARM CONDITION
}

\author{
O. V. Matsenko, V. M. Mogilyovskyy, O. V. Mitrofanov, Yu. V. Maslak, \\ Yu. O. Shchepetilnikov, V. A. Pasechnik, I. V. Furda \\ Kharkiv State Zooveterinary Academy, Ukraine
}

Article info

Received 18.02.2019

Received in revised form

25.02.2019

Accepted 04.03.2019

Kharkiv State Zooveterinary

Academy

Akademichna str., 1, Mala

Danylivka, Dergachivsky

district, Kharkiv region,

Ukraine, 62341

E-mail:

elenam57722@gmail.com
Matsenko, O. V., Mogilyovskyy, V. M., Mitrofanov, O. V., Maslak, Yu. V.,Shchepetilnikov, Yu. O., Pasechnik, V. A., \& Furda, I. V. (2019). The complex scheme of prevention of gastrointestinal diseases of piglets in farm condition. Veterinary science,technologies of animal husbandry and nature management, 3, 144-153. doi: 10.31890/vttp.2019.03.20.

The materials of using a complex of pharmacological drugs for pigs for the prophylaxis of gastrointestinal diseases are presented in this article. Animals from the experimental group from the $23 r d$ to the 75 th day of life during 7 days received a complex of medicinal products: Brovasceptol - $350 \mathrm{~g}$, Ultracid - $100 \mathrm{~g}$, zinc oxide - $100 \mathrm{~g}$, Lactysan - $50 \mathrm{~g}$, and feed additive Starter BVMD for $100 \mathrm{~kg}$ of mixed fodder. The piglets of the control group received a similar feed, but without probiotic Lactysan. Brovaseptol was used in both groups for 14 days from the beginning of the experiment, and the rest of the drugs were added continuously to 75 days of life. The studies determined the increment of pigs, taking into account their preservation and conversion of feed. We used generally accepted methods for clinical examination of animals. In the blood serum of animals, the content of total protein, total calcium, inorganic phosphorus, alkaline reserve, activity of the enzymes AsAt and AlAt were determined. The obtained results were statistically processed in the Exel program.

The animals of the experimental group were clinically healthy, had a higher control over body weight (by $23 \%$, by $9 \%$, by $30 \%$ by $5 \%$, by $45 \%$ by $5 \%$, and by $75 \%$ by $12 \%$ ) and by $100 \%$ preservation. In addition, the cost of feed per $\mathrm{kg}$ of live weight in piglets of this group was lower by $9.5 \%$ compared to the indicators in control.

Concentration of total protein in blood serum both groups were within the limits before weaning process, this indicate that feeding of sows on the farm was complete, but on the 75th day of life in animals of the experimental group, concentration of total protein was higher than in the control group.

Changes in the level of mineral metabolism of piglets during the period of cultivation did not occur, as the animals were provided with balanced feed additives, additives and a complex of pharmacological drugs, which prevented dysfunction of the stomach and intestines and 
contributed to the complete assimilation of basic and biologically active substances.

The alkaline reserve of blood serum of animals during the experiment was within the normal range, which indicated the physiological content in the tissues of organic acids, the violation of which occurs due to metabolic acidosis due to intoxication of the body with gastrointestinal disorders and other pathologies.

In animals of experimental group the activity of transaminases decreased on the 30th day - 35.2 \pm 4.43 and 19.6 \pm 3.2 , and on the 75th day $-28,0 \pm 3.76$ and 17,0 $\pm 2.07 \mathrm{U} / \mathrm{I}$, on the other hand the activity of enzymes in the control group increased: 36,0 \pm 5,3 and 20,4 $\pm 4,9$ to37, $0 \pm 5,38$ and 23,0 $\pm 2,8 \mathrm{U} / \mathrm{l}$, respectively. The activity of AsAt decreased by $20 \%$, and AlAt - by $13 \%$ on the 75 th day of life compared with the 30 th day. The activity of AsAt increased by $3 \%$ and AlAt by $13 \%$ in animals from control group

Consequently, rational prevention of gastro-intestinal diseases of piglets is the organization of full and high-quality feeding of the breeding stock, the creation of proper conditions for the maintenance of pigs and piglets, and the reduction of the influence of stress factors by introducing complex supplements with feeds in order to optimize metabolic processes, activate mechanisms of non-specific resistance of young animals at weaning period, which increases the growth and conservation of the livestock.

Key words: prophylaxis, antimicrobials, probiotics, acidifying agent, gastrointestinal diseases, metabolism, piglets.

\title{
КОМПЛЕКСНАЯ СХЕМА ПРОФИЛАКТИКИ ЖЕЛУДОЧНО-КИШЕЧНЫХ ЗАБОЛЕВАНИЙ ПОРОСЯТ В УСЛОВИЯХ ФЕРМЕРСКОГО ХОЗЯЙСТВА
}

\author{
Е. В. Маценко, В. Н. Могилевский, А. В. Митрофанов, \\ Ю. В. Маслак, Ю. А. Щепетильников, В. А. Пасечник, И. В. Фурда \\ Харьковская государственная зооветеринарная академія, Харьков, Украина
}

Изложены материалы относительно применения комплекса фрармакологических препаратов поросятам с целью профилактики желудочно-кишечных заболеваний. Животным опытной группы с 23-го по 75-й день жизни за 7 дней до отъема от свиноматки на 100 кә комбикорма добавляли комплекс лекарственных средств : Бровасептол - 350 2, Ультрацид - 100 г, оксид цинка - 100 г, Лактисан - 50 г и кормовую добавку Стартер БВМД. Поросята контрольной группы получали аналогичный комбикорм, но без пробиотика Лактисан. Препарат Бровасептол применяли в обеих группах на протяжении 14 дней с начала эксперимента, остальные препараты добавляли постоянно до 75 дня жизни животных. В исследованиях определяли прирост поросят, учитывали их сохранность и конверсию корма. Клинические исследования животных проводили общепринятыми методами. В сыворотке крови животных определяли содержание общего белка, общего кальция, неорганического фросфрора, щелочного резерва, активность ферментов АсAт и АлАT. Полученные результаты обрабатывали статистически в программе Exel.

Животные опытной группы были клинически здоровыми, имели выше, чем в контроле массу тела (на 23-й день - на 9 \%, 30-й- на $5 \%$, 45-й - на $5 \%$ и 75-й - на 12\%) и 100\% сохранность. К тому же, затраты кормов на 1 ке живого веса поросят данной группы были меньше на 9,5\% против показателей в контроле. При проведении биохимических исследований сыворотки крови поросят было установлено, что у опытных и контрольных животных перед отъемом содержание общего белка находилось в пределах фризиологических показателей.

Изменений минерального метаболизма поросят за период выращивания не наблюдали, поскольку животные были обеспечены сбалансированными кормами, добавками и комплексом фрармакологических препаратов, которые предотвращали дисфункции желудка и кишечника и способствовали полной ассимиляции основных биологически активный субстанций. 
Щелочной резерв сыворотки крови животных за период проведения опыта находился в пределах нормы, что свидетельствовало о фризиологическом содержании в тканях органических кислот, нарушение количества которых происходит при метаболическом ацидозе в результате интоксикации организма при желудочно-кишечных расстройствах и других патологиях.

У поросят опытной группы отмечена тенденция к снижению активности трансаминаз на 30-й день -

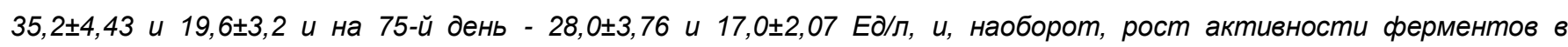

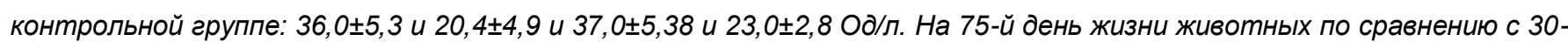
м днем, активность АсАт снижалась на 20\%, а АлАт - на 13\%. У поросят контрольной группы отмечали обратную тенденцию - рост активности АсAm - на 3\% и АлAm - на 13\%. Следовательно, рациональной профрилактикой желудочно-кишечных заболеваний поросят является организация полноценного и качественного кормления маточного поголовья, создания надлежащих условий содержания свиней и поросят, снижение влияния стрессовых факторов путем введения с кормами комплексных добавок с целью оптимизации процессов метаболизма, активизации механизмов неспецифической резистентности молодняку при отъеме, что повышает приросты и сохранностью поголовья.

Ключевые слова: профилактика, антимикробные препараты, пробиотики, подкислители, желудочно-кишечные заболевания, обмен веществ, поросята.

\title{
КОМПЛЕКСНА СХЕМА ПРОФІЛАКТИКИ ШЛУНКОВО-КИШКОВИХ ХВОРОБ ПОРОСЯТ В УМОВАХ ФЕРМЕРСЬКОГО ГОСПОДАРСТВА
}

\author{
О. В. Маценко, В. М. Могільовський, О. В. Митрофранов, \\ Ю. В. Маслак, Ю. О. Щепетільніков, В. А. Пасічник, І. В. Фурда \\ Харківська державна зооветеринарна академія, Харків, Україна
}

Викладені матеріали щодо застосування комплексу фрармакологічних препаратів (антимікробні, пробіотичні, органічні кислоти, цинк) з метою профрілактики шлунково-кишкових захворювань у поросят. Встановлено, що введені до складу комбікорму досліджувані препарати відновлювали нормальну мікрофрлору кишечнику поросят біологічним шляхом та створювали несприятливі умови для бурхливого розвитку умовно-патогенних мікроорганізмів за зниження резистентності організму поросят у відлучний період. Нормалізація фрункції кишечнику, зменшення ендогенної інтоксикації сприяли активізації механізмів неспецифрічної резистентності молодняку при відлученні, що підвищувало збереженість та прирости поголів'я.

Ключові слова: профрілактика, антимікробні препарати, пробіотики, підкислювач, шлунково-кишкові хвороби, обмін речовин, поросята.

\section{Вступ}

Актуальність теми. Сучасне свинарство високорентабельна і технологічна галузь тваринництва, що динамічно розвивається в усіх країнах світу, але найбільшого поширення набула в Америці, Європі та Східній Азії. Лідерами з виробництва свинини в Євросоюзі є Німеччина (59,4 млн. або 23\% від загальної кількості в ЄС) та Іспанія (47,7 млн. або 19\%), за ними Франція (23,8 млн, 9\%), Польща (21,8 млн, 8\%), Данія (18,2 млн, 7\%), Нідерланди (15,4млн, 6\%), Італія (11,8 млн, 5\%), Бельгія (11,2 млн, 4\%) і Великобританія (11,0 млн, 4\%) (Pork production up in the EU - Eurostat; EU Monthly Pig Meat Production Trends - AHDB). У країнах 3 розвиненим свинарством основна частина підприємств - це невеликі приватні ферми, де працівники безпосередньо є їх власниками. Так, у Китаї на великих промислових комплексах вирощується лише $4 \%$ поголів'я свиней, в Північній Америці - близько 30\%, а в Центральній і Східній Європі - 50\%. У Нідерландах, Данії, Англії та Франції майже 90\% поголів'я утримується на невеликих фермах (Proizvodstvo svininyi za rubezhom).

На сьогодні в Україні виробництвом свинини займаються фермерські господарства та великі агрохолдінги, при цьому, в індивідуальних господарствах виробляється близько 62-65\% свинини 
від загальної ії кількості (Rybalko, 2010; «ladro» svynarskoi haluzi - 50-80 hospodarstv).

Як відомо, технології утримання свиней у промислових агропідприємствах та невеликих фермерських господарствах суттєво відрізняються. Ці особливості безпосередньо впливають на здоров'я тварин, змінюючи рентабельність та прибутковість цього бізнесу. Дія негативних фракторів часто призводить до захворювань поросят внаслідок порушень метаболізму, адаптаційних механізмів, зниження загальної резистентності організму та розвитку імунодефіцитів, особливо в період відлучення їх від свиноматки. У напружений період відлучення поросят, дієвим запобіжним заходом є згодовування $з$ кормом лікувальних препаратів у профілактичних дозах.

Аналіз останніх досліджень $і$ публікацій. Найбільш поширеними шлунково-кишковими та респіраторними захворюваннями поросят $€$ неонатальна діарея (колібактеріоз, коліентеротоксемія), ексудативний дерматит (greasy pig - Staphlococcus hyicus), кокцидіоз (кривава діарея), дизентерія свиней (Brachyspira hyodsenteriae), сальмонельоз, респіраторні хвороби (Swine Respiratory Disease - SRD, Streptococcus suis, Pasteurella), плевропневмонія (Actinobacillus pleuropneumoniae), кормова алергія (Hollis, 2003; Kay, 2019; Penrith, 2001).

Відомо, що гемохоріальна плацента свиней не пропускає материнські імуноглобуліни (lg), тому для новонароджених поросят необхідне їх своєчасне надходження від матері. Окрім глюкози та жирів, 3 молозивом поросята отримують альбуміни, глобуліни, $\operatorname{lgG}$, $\lg$ та $\operatorname{lgA}$, Т- і В-лімфоцити, нейтрофріли i макрофраги, які забезпечують захист і стимулювання імунної системи та попереджають інфікування в ранньому віці. IgА забезпечує захист слизових оболонок шлунково-кишкового тракту. В кишківнику імунна система контактує з патогенами, тому в ньому міститься більшість імунних клітин організму. Епітелій кишечнику виступає першою лінією захисту від патогенної мікрофрлори та токсинів, тому порушення його цілісності призводить до всмоктування токсинів, що спричиняє розлади травлення, зневоднення, інтоксикацію, зниження загальної резистентності організму та загибель. Кишкова мікрофлора забезпечує засвоєння багатьох поживних речовин корму та запобігає розвитку патогенних мікроорганізмів. При переведенні молодняка з годівлі молоком на сухий корм, або зміні складу раціону, в кишечнику змінюється висота ворсинок і глибина крипт (можливо до атрофії), що знижує засвоєння корму та спричиняє розвиток запальних процесів (Foisnet, Farmer, David, \& Quesnel, 2010; Swine Respiratory Disease (SRD); Bojkovski, Stanković, Maletić, Dobrosavljević, Zdravković, Vasić, \& Delić, 2015).

Більшість фермерів всього світу використовують протимікробні засоби для профілактики захворювань, або стимуляції росту, а популярність антибіотикотерапії частково виправдовують її ефрективністю. Але, оскільки в тваринництві використовується більше антибіотичних препаратів, ніж в медицині, зростає стурбованість 3 приводу розширення числа стійких бактерій, що проникають в організм людини 3 продуктами харчування. Стійкість до протимікробних препаратів (Bacterial antimicrobial resistance (AMR) загрожує здоров'ю тварин і людини у всьому світі і вимагає відповідних заходів на усіх ланках виробничого ланцюга тваринництва. Протимікробні препарати дійсно необхідні людям і тваринам для захисту від патогенних бактерій, які можуть викликати захворювання або загибель, проте резистентність до протимікробних препаратів загрожує їх ефективності. Навіть Всесвітня організація охорони здоров'я (ВООЗ) в 2014 році заявила, що ситуація зі стійкістю до протимікробних препаратів настільки серйозна, що ми вступаємо в "епоху після антибіотиків", коли звичайні інфекції і незначні травми будуть причиною летальності людей і тварин (Berge, 2018; Antimicrobial Resistance, 2019).

Антибіотики порушують кишковий мікробіоценоз, внаслідок чого зростає вірулентність ешерихій і сальмонел, тому після призначення цих препаратів необхідне відновлення нормальної мікрофрлори кишечнику, яка контролює патогенність і стримує чисельність грамнегативних мікроорганізмів (Akwar,Poppe, Wilson,Reid-Smith, Dyck, Waddington,\& McEwen, ,2008; Animal Nutrition Products: Bio-Mos®).

Найефрективнішими лікувально-профрілактичними заходами за шлунково-кишкових захворювань у поросят $€$ запровадження сучасних технологій захисту кишечника, розроблених за допомогою нутригеноміки та застосування безпечних препаратів органічних кислот та пробіотиків, як наприклад Bio-Mos, Actigen, Mycosorb та інші (Berge, 2018; Animal Nutrition Products: Bio-Mos®; The best start for piglets). Відомо, що при переході поросят на годівлю високопротеїновими кормами критично змінюється $\mathrm{pH}$ в шлунку, а тому не забезпечується повноцінне перетравлювання та 
засвоєння нутрієнтів, що підвищує ризик розвитку (за pH 6,0-8,0) патогенної мікрофрлори (E.coli, Salmonella) в товстому кишечнику, звідки вони потрапляють в тонкий кишечник, закріплюються на ворсинках епітелію та спричиняють проноси. Тому для корекції кислотності до корму додають підкислювачі, які у своєму складі зазвичай містять органічні кислоти: мурав'їну, пропіонову, фумарову, молочну, лимонну, бензойну, сорбінову, оцтову та масляну. Під дією цих кислот знижується рН, активізуються фрерменти шлунку, підшлункової залози і кишечнику, стимулюється розвиток ворсинок епітелію тонкого кишечнику, що знижує всмоктування токсинів та пригнічує розвиток патогенної мікрофрлори (Liao, \& Nyachoti, 2017; Alakomi, Skyttä, Saarela, Mattila-Sandholm, Latva-Kala, \& Helander, 2000).

Альтернативою антибіотикам у свинарстві $€$ високоефективний кормовий пробіотик від европейського виробника (JHJ Sp. z о.о., Польща) «Lactisan» (Лактисан комплекс), виготовлений унікальним ферментним методом, в якому поєднані штами бактерій та дріжджі: Lactococcus lactis покращує використання корму, стимулює вироблення ензізмів, засвоєння вуглеводів та синтез бактеріоцинів; Carnobacterium divergens - стимулює імунну систему; Lactobacillus casei та Lactobacillus plantarum - покращує використання корму, стимулює вироблення бактеріоцинів і перекису водню; Saccharomyces cervisae - покращує використання корму, симбіоз 3 молочнокислими бактеріями, нейтралізує мікотоксини (Kormovyi probiotyk Laktisan Kompleks (Lactisan Complex)).

Відомо, що за шлунково-кишкових розладів у поросят порушується мінеральний обмін, внаслідок чого різко знижується продуктивність, подовжується адаптація до стресів, і як наслідок - зростає захворюваність і загибель молодняку. Від умісту цинку у кормах залежить діяльність мікрофрлори кишечнику, а за його дефіциту (у плазмі менше 0,4 мг/л) організм поросят швидко реагує розвитком патологічних змін: порушується кісткоутворення та ороговіння клітин епідермісу (паракератоз). Zn є компонентом мембран, клітинних рецепторів, протеїнів, входить до складу більше 200 ензиматичних систем, впливає на життєво важливі гормони як інсулін, кортикотропін, соматотропін, гонадотропін та ферменти, як: енолази, гістідази, депептідази, амілази. Висока концентрація цинку в підшлунковій залозі, гіпофрізі і статевих залозах.
Zn впливає на обмін сечової кислоти, білків, жирів, вуглеводів і вітамінів, життєво необхідний для гемопоезу. Zn є складовою карбоангідрази, яка регулює в крові уміст $\mathrm{CO}_{2}$, карбоксипептидази підшлункової залози і дегідрогенази глутамінової кислоти (Sudakov et al., 1991; Carlson, Poulsen, \& Sehested, 2004; Burch, 2014). Дієвим засобом профрілактики діареї відлучених поросят $€$ введення до раціону тварин оксиду цинку (Ratsion dlia vidluchentsiv: alternatyvy oksydu tsynku).

Таким чином, превентивними заходами за шлунково-кишкових розладів у поросят у період їх відлучення $\epsilon$ створення для них належних умов утримання і годівлі, зменшення впливу стрес-факторів, профрілактика порушень метаболізму та нормалізація мікрофлори їх кишечнику.

Mета роботи - профілактика шлунковокишкових розладів у відлучених поросят 3 використанням сучасних кормових добавок і лікарських засобів.

Завдання дослідження: дослідити ефективність комплексної схеми профрілактики шлунково-кишкових розладів у поросят із застосуванням протимікробного засобу Бровасептол, пробіотику Lactisan Complex, підкислювача кормів -Ультрацид $\ln U$ Плюс сухий, та цинку у формі оксиду, введених до складу комбікорму.

\section{Матеріал і методи досліджень}

Досліди проводились в умовах приватного фермерського господарства «Мета» Дергачівського району Харківської області. Матеріалом для досліджень були поросята (беконна трипородна помісь) від 23-х до 75-ти денного віку, живою вагою від 5 до 35 кг, отриманих від свинок Б-1 (кБ-Ландрас), які були запліднені спермою хряків (Дюрок або Макстер-304).

Проводили аналіз утримання та годівлі свиней. В раціонах свиноматок і поросят визначали кількість сухої речовини, обмінної енергії, сирого жиру, сирої клітковини та сирого протеїну, амінокислот: лізину, метионіну+цистину, триптофрану, мінералів - кальцію, фоссрору та натрію. Загальноприйнятими методами проводили клінічне обстеження тварин та вивчали зміни біохімічних показників в сироватці крові поросят (Pavlov, Yakovleva, Mytrofanov, \& Mohilovskyi, 2005). Схема досліджень передбачала згодовування поросятам дослідної групи $(\mathrm{n}=20)$ за 7 днів до відлучення від свиноматки спеціального комбікорму 3 додаванням лікувальних засобів та кормових домішок: на 100 кг комбікорму додавали лікарські засоби: Бровасептол - 350 г, Ультрацид - 100 г, оксид цинку - 
100 г, Lactisan - 50 г та кормову добавку Стартер БВМД. Поросята контрольної групи $(\mathrm{n}=20)$ отримували аналогічний комбікорм, але без пробіотика Lactisan.

Препарат Бровасептол застосовували в обох групах упродовж 14 днів з початку експерименту, решту препаратів до корму додавали постійно до 75 дня життя тварин і досягненню ними живої маси 30-35 кг. Умови утримання поросят обох груп протягом експерименту не змінювались.

У дослідженнях визначали живу вагу поросят при народженні, на 23-й (за 7 днів до відлучення), 30-й, 45-й та 75-й день життя, також враховували їх збереженість. Клінічні дослідження тварин проводили загальноприйнятими методами.

На 30-у та 75-у добу у поросят, відбирали кров з орбітального синуса і отримували сироватку, в якій визначали вміст загального білка, загального кальцію, неорганічного фоссрору, лужного резерву, активність ферментів АсАт і АлАТ. Дослідження проводили в лабораторії «БАТ» м. Харкова. Отримані результати обробляли статистично в програмі Exel.

\section{Результати та їх обговорення}

Утримання свиней у приватному фермерському господарстві відповідало діючим ветеринарносанітарним нормам. Згідно плану профілактичних заходів проводились щеплення поголів'я свиней проти класичної чуми, бешихи і лептоспірозу. Господарство вважається благополучним з інфекційних хвороб.

Раціон годівлі свиноматок, В основному, забезпечував потреби тварин в поживних речовинах.

За технологією розведення свиней в господарстві, 3 5-денного віку поросят підгодовують предстартерним комбікормом Фідлайфр (Feed\&Life, Україна), а з 23-денного віку згодовують комбікорм власного виробництва з ячменю, кукурудзи і пшениці у співвідношенні $1: 1: 1$, та додаванням 25\% кормової добавки Cmapmep БВМД (Feed\&Life) 3 якісною характеристикою: протеїн - 15-16\%, клітковина - до 4,5\%, кальцій і фоссфор - 0,9\%, що відповідає вимогам для даної групи поросят. Відлучення поросят від свиноматки проводиться на 30-й день.

Аналіз виробничих показників у період від відлучення поросят до 75-го дня життя представлений на графріку 1 та в таблиці 1, з яких видно, що середньодобовий приріст ваги у дослідній групі складав 550 г і був більшим на 12\% ніж у контролі, де склав 490 г. Важливо відмітити, що протягом всього дослідження приріст маси у дослідних поросят був вищим ніж у контрольних, відповідно, на 23-добу - на 9\%, 30-у - на $5 \%, 45-y-$ на $5 \%$ та $75-y-$ на $12 \%$.

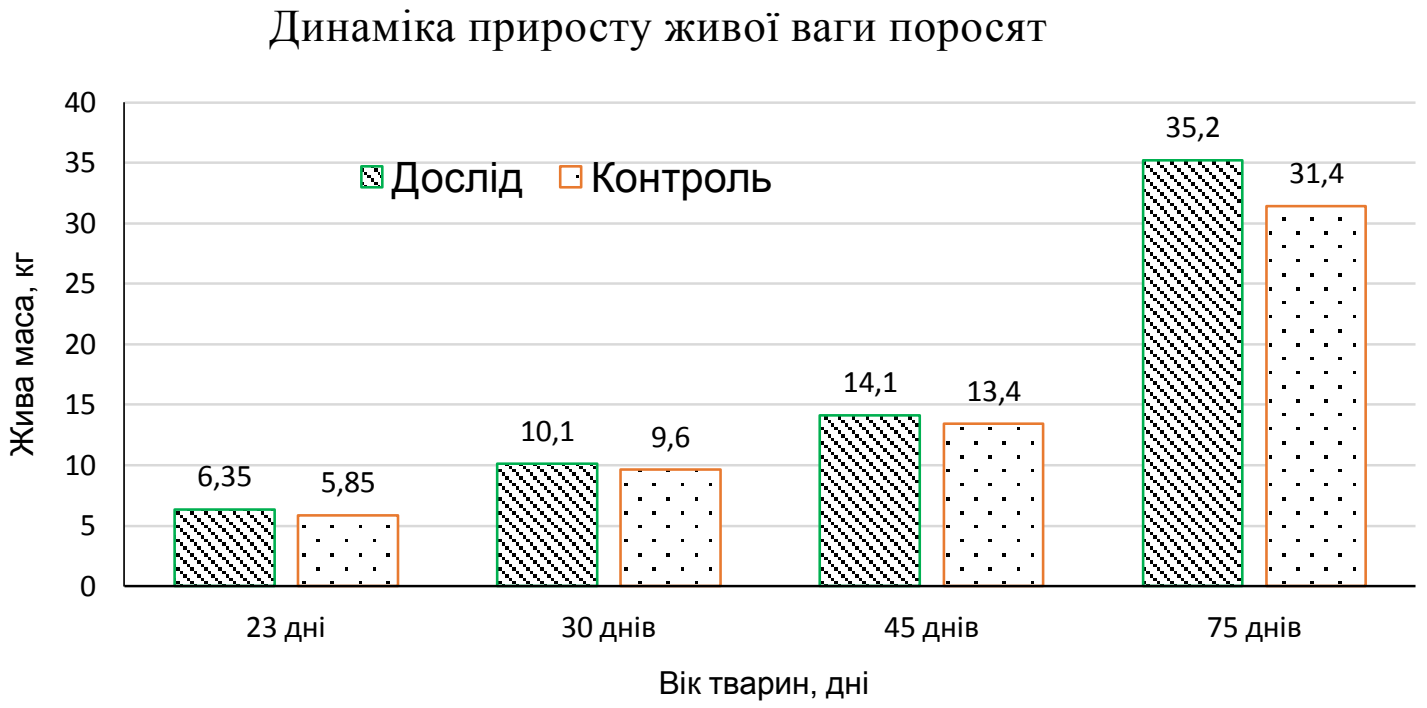


Виробничі показники вирощування поросят

\begin{tabular}{|c|c|c|c|}
\hline \multirow{2}{*}{ Показники } & \multirow{2}{*}{ Одиниці } & \multicolumn{2}{|c|}{ Група } \\
\hline & & Дослід & Контроль \\
\hline Тварин на початок досліду & гол & 20 & 20 \\
\hline Середньодобовий приріст за період досліду (52 дні) & $r$ & 550 & 490 \\
\hline Збереженість тварин & $\%$ & 100 & 95 \\
\hline Конверсія корму & КГ & 3,8 & 4,2 \\
\hline
\end{tabular}

Таким чином відлучка поросят $€$ напруженим стресовим періодом їх вирощування. У відлучених поросят упродовж 2-х тижнів спостерігалось зниження приросту живої ваги, що свідчило про перебудову процесів травлення та зміни в метаболізмі. Крім того, у цей віковий проміжок проявляється імунний дефіцит, тому відлучені поросята перебувають у групі ризику до захворювань.

Особливості розвитку і фрункціювання травної системи поросят потребують корекції годівлі: у період підсосу - $з$ престартером, період відлучення - зі стартерним комбікормом і в період дорощування комбінованими кормами. Спеціально розроблені престартерні корми для періоду відлучення 3 високоякісними компонентами у поєднанні 3 застосованими нами кормовими добавками i лікарськими препаратами стимулювали розвиток і стабільне функціювання травної системи поросят.

За період спостережень, в контрольній групі поросята хворіли шлунковими розладами 3 діарею i одна тварина загинула. У дослідній групі поросята були клінічно здоровими і в цій групі було встановлено покращення конверсії корму, тобто затрати кормів на 1 кг живої ваги поросят були меншими на 9,5\% проти показників контрольної групи, що свідчило про краще засвоєння поживних речовин та ефрективність застосованих заходів, а отже і підвищення рентабельності виробництва.

Проведеним ветеринарним оглядом тварин на 23-й день життя було встановлено активність поросят, їх задовільний фрізіологічний розвиток і відповідність маси тіла віку та породі (у середньому 6,1 кг). При обстеженні поголів'я клінічних проявів порушень серцево-судинної, дихальної, травної, сечової та нервової систем у поросят не спостерігали.

При проведенні біохімічних досліджень сироватки крові поросят на 30-й та 75-й день життя було встановлено, що у дослідних та контрольних тварин у період відлучення уміст загального білку знаходився у межах фрізіологічних коливань 70-72 г/л, що свідчило про повноцінну годівлю свиноматок у господарстві та своєчасність превентивних заходів щодо шлунково-кишкових хвороб у молодняку (таблиця 2).

Протягом досліджень стан мінерального обміну у поросят обох груп знаходився у межах фізіологічних показників і за період вирощування не змінювався. Так, умісту загального кальцію: на 30-у добу у досліді -

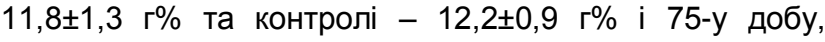

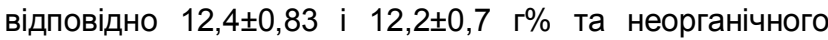

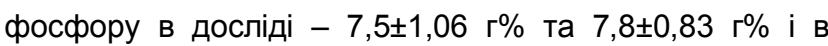
контролі $-7,3 \pm 0,25$ г\% та 7,6 00,86 г\%.

Таблиця 2

Біохімічні зміни в крові поросят

\begin{tabular}{|c|c|c|c|c|c|c|}
\hline \multirow{2}{*}{ Показники } & \multirow{2}{*}{$\begin{array}{l}\text { Oд. } \\
\text { виміру }\end{array}$} & \multirow{2}{*}{ Lim } & \multicolumn{2}{|c|}{$\begin{array}{l}\text { Дослідна група } \\
(n=20)\end{array}$} & \multicolumn{2}{|c|}{$\begin{array}{c}\text { Контрольна група } \\
\qquad(n=20)\end{array}$} \\
\hline & & & 30-й день & 75-й день & 30-й день & 75-й день \\
\hline Загальний білок & г/ת & $70-85$ & $72 \pm 3,5$ & $81 \pm 4,8^{*}$ & $70 \pm 2,4$ & $76 \pm 5,0$ \\
\hline
\end{tabular}




\begin{tabular}{|l|l|l|l|l|l|l|}
\hline Загальний кальцій & г\% & $10-14,2$ & $11,8 \pm 1,3$ & $12,4 \pm 0,83$ & $12,2 \pm 0,9$ & $12,2 \pm 0,7$ \\
\hline Неорган. фосфор & г\% & $6-9$ & $7,5 \pm 1,06$ & $7,8 \pm 0,83$ & $7,3 \pm 0,25$ & $7,6 \pm 0,86$ \\
\hline Лужний резерв & Об.\% $\mathrm{CO}_{2}$ & $45-51$ & $46,0 \pm 2,5$ & $47,2 \pm 1,9$ & $45,6 \pm 3,04$ & $45,8 \pm 4,4$ \\
\hline АсАТ & Од/л & $10-35$ & $35,2 \pm 4,43$ & $28 \pm 3,76^{*}$ & $36 \pm 5,3$ & $37 \pm 5,38$ \\
\hline АлАт & Од/л & $5-20$ & $19,6 \pm 3,2$ & $17 \pm 2,07^{*}$ & $20,4 \pm 4,9$ & $23 \pm 2,8$ \\
\hline
\end{tabular}

Примітка: * - P>0,95

Аналіз встановлених даних дає підстави зробити висновок про достатній уміст цих елементів у молоці свиноматки, доцільність збалансованості раціону добавкою «Cтартер БВМД» та есрективності застосування досліджуваних добавок.

Як відомо, лужний резерв сироватки крові характеризує стан кислотно-лужної рівноваги організму. За період проведення досліду, в обох групах поросят ці показники знаходились у межах норми, у дослідних поросят - 46,0 $\pm 2,54$ та $47,2 \pm 1,9$ та в контролі $45,6 \pm 3,04$ та $45,8 \pm 4,38$ Об.\% $\mathrm{CO}_{2}$, що свідчило про фізіологічний вміст у тканинах органічних кислот, порушення кількості яких відбувається за метаболічного ацидозу внаслідок інтоксикації організму при шлунковокишкових розладах та інших патологіях.

Застосування досліджуваного комплексу добавок та лікарських засобів з основним комбікормом у годівлі поросят позитивно впливало на функцію печінки, про що свідчили показники АсАТ та АлАТ. Аналізуючи встановлені дані, слід відмітити тенденцію до зниження активності трансаміназ у поросят дослідної групи: на

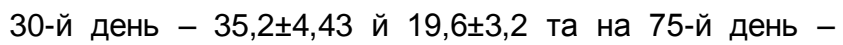
$28 \pm 3,76$ й $17 \pm 2,07$ Од/л, та, навпаки, підвищення активності ферментів у контрольних тварин: $36 \pm 5,3$ й $20,4 \pm 4,9$ та $37 \pm 5,38$ й $23 \pm 2,8$ Од/л. У дослідних поросят, на 75-й день в порівнянні з 30-м днем активність АсАт знижувалась на $20 \%$, а АлАт - на $13 \%$. У контрольних поросят це порівняння показало зворотну тенденцію - зростання активності АсАт - на $3 \%$ та АлАт - на 13\%. Клінічна інтерпретація встановлених показників дає підстави визначити активний вплив негативних чинників на печінку поросят за відлучення, а також відзначити гепатопротекторний ефрект досліджуваної схеми.

Таким чином, за результатами проведених досліджень встановлено, що раціональною профрілактикою шлунково-кишкових хвороб поросят $€$ організація повноцінної і якісної годівлі маточного поголів'я, створення належних умов утримання свиней i поросят, зниження впливу стрес-фракторів та використання кормових добавок. В той же час, ефективність таких заходів може бути недостатньою, якщо нехтувати станом кишкового біоценозу, відновлення якого досягається своєчасним застосуванням молодняку комплексних препаратів 3 симбіонтної мікрофрлори, оптимізацією процесів метаболізму та активізацією механізмів неспецифрічної резистентності поросят при відлученні, що дозволяє не лише ефективно попереджувати розлади травлення, але й сприяти кращому розвитку та збереженості молодняку.

\section{Висновки}

1. Технологія утримання та годівлі свиноматок i поросят у приватному фермерському господарстві відповідає зоотехнічним вимогам, що дозволяє отримувати якісну свинину.

2. Відлучення поросят від свиноматок та переведення їх на годівлю комбінованими кормами призводить до технологічного стресу, що супроводжується шлунково-кишковими розладами та загибеллю 5 \%тварин, зменшенням у 1,2 рази середньодобових приростів за період вирощування та збільшення у 1, 2 рази конверсії корму.

3. За адаптації відлучених поросят контрольної групи до змінених умов їх утримання i годівлі на 75-й день життя зменшувався вміст білка 76 $\pm 5,0$ г/л проти $81 \pm 4,8$ г/л у тварин дослідної групи.

4. Показники мінерального обміну за період вирощування поросят суттєво не змінювались, що свідчило про повноцінну годівлю тварин: вміст загального кальцію та органічного фоссрору у досліді

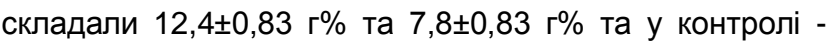
$12,2 \pm 0,7$ г\%та 7,6 $\pm 0,86$ г\%. 
5. Введення 3 кормом досліджуваного комплексу фрармакологічних препаратів покращувало функціональний стан печінки, на що вказували нижчі, ніж у контролі показники активності трансаміназ (АсАТ -

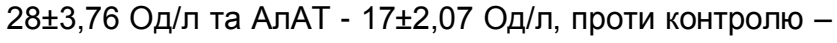

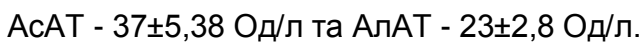

6. Ефеккивним лікувально-профрілактичним заходом за шлунково-кишкових хвороб з синдромом діареї у відлучених поросят $є$ згодовування на 100 кг комбікорму Бровасептолу - 350 г, Ультрациду - 100 г, оксиду цинку - 100 г, Lactisan - 50 г та кормової добавки Cтартер БВМД, що дозволяє підвищити збереженість молодняку, отримати більш високі прирости живої ваги тварин та знизити затрати кормів.

Перспективи подальших досліджень. Порушення умов утримання i годівлі свиноматок i поросят у господарствах, дія технологічних стресфакторів $€$ причиною зниження природної резистентності тварин, дисбалансу метаболізму, що призводить до розвитку шлунково-кишкових захворювань з синдромом діареї, які найчастіші у молозивний період та при відлученні і $€$ причиною зниження прибутковості виробництва. Подальші дослідження будуть спрямовані на розробку лікувальнопрофілактичних заходів шляхом додаткового введення до кормів пробіотиків, сорбентів, адаптогенів та імуномодуляторів.

\section{References}

«ladro» svynarskoi haluzi - 50-80 hospodarstv. PigUA.info. Retrieved from http://pigua.info/uk/post/adrosvinarskoi-galuzi-50-80-gospodarstv-uk (in Ukraine).

Akwar, H.T., Poppe, C., Wilson, J., Reid-Smith, R.J., Dyck, M., Waddington, J., \& McEwen, S.A. (2008). Prevalence and patterns of antimicrobial resistance of fecal Escherichia coli among pigs on 47 farrowtofinish farms with different in-feed medication policies in Ontario and British Columbia. Canadian Journal of Veterinary Research, 72, 195-201.

Alakomi, H.-L., Skyttä, E., Saarela, M., Mattila-Sandholm, T., Latva-Kala, K., \& Helander, I.M. (2000). Lactic acid permeabilizes gram-negative bacteria by disrupting the outer membrane. Applied and Environmental Microbiology, 66.(5), 2001-2005. doi: 10.1128/AEM.66.5.2001-2005.2000.

Animal Nutrition Products: Bio-Mos $®$. Retrieved from https://www.alltech.com/bio-mos
Antimicrobial Resistance. (2019). Retrieved from https://thepigsite.com/focus/amr/4269/antimicrobialresistance

Berge, C. (2018). Antibiotic angst: Antimicrobial resistance in pig production. Retrieved from https://www.alltech.com/podcast-blog/dr-cat-berge

Birkegård A. C., Halasa T., Græsbøll K., Clasen J., Folkesson A., \& Toft N. (2017). Association between selected antimicrobial resistance genes and antimicrobial exposure in Danish pig farms. Scientific Reports, 7, 9683. doi:10.1038/s41598017-10092-9

Bojkovski, J., Stanković, B., Maletić, M., Dobrosavljević, I., Zdravković, N., Vasić, A., \& Delić, N. (2015). Diseases of suckling piglets health and reproduction problem on commercial farm. 4th International Congress New Perspectives and Challenges of Sustainable Livestock Production, 7-9 October. 2015, Belgrade, Serbia. Retrieved from https://www.researchgate.net/publication/28308155 8.

Burch, D. (2014). The Role of Zinc for. Piglet Health. Retrieved from http://www.octagonservices.co.uk/articles/zinc.pdf

Carlson, D., Poulsen, H. D., \& Sehested, J. (2004). Influence of weaning and effect of post weaning dietary zinc and copper on electrophysiological response to glucose, theophylline and $5-\mathrm{HT}$ in piglet small intestinal mucosa. Comparative Biochemistry and Physiology. Part A, Molecular \& Integrative Physiology, 137(4), 757-765. doi: 10.1016/j.cbpb.2004.02.011.

EU Monthly Pig Meat Production Trends - AHDB. Retrieved from https://pork.ahdb.org.uk/pricesstats/production/eu-monthly-pig-meat-productiontrends/

Foisnet, A., Farmer, C., David, C., \& Quesnel, H. (2010). Relationships between colostrum production by primiparous sows and sow physiology around parturition. J. Anim Sci., 88(5),1672-1683. doi: 10.2527/jas.2009-2562.

Hollis, W. (2003). Prevention vs. Treatment of Disease. National Hog Farmer. Retrieved from https://www.nationalhogfarmer.com/mag/farming $\mathrm{pr}$ evention vs treatment.

Kay, Z. (2019). 6 most common pig diseases. Retrieved from https://www.wattagnet.com/articles/25841most-common-pig-diseases-worldwide. 
Kormovyi probiotyk Laktisan Kompleks (Lactisan Complex).

Retrieved from https://kormagro-

t.ub.ua/ua/goods/view/8602871/all/kormoviy-

probiotik-laktisan-kompleks-lactisan-complex

Liao, S. F., \& Nyachoti, M. (2017). Using probiotics to improve swine gut health and nutrient utilization.

Animal Nutrition, 3(4), 331-343.

do:10.1016/i.aninu.2017.06.007.

Pavlov, M.le., Yakovleva, O. H., Mytrofanov, O. V., \&

Mohilovskyi. V. M. (2005). Biokhimichni

doslidzhennia $v$ diahnostytsi vnutrishnikh khvorob tvaryn. Kharkiv. (in Ukrainian).

Penrith, M-L. (2001). Common diseases of small pig herds.

Retrieved from

http://www.daff.gov.za/daffweb3/Portals/0/InfoPaks/

Common\%20diseases\%20of\%20small\%20pig\%20h

erds.pdf .

Pork production up in the EU - Eurostat. Retrieved from

https://ec.europa.eu/eurostat/en/web/products-

eurostat-news/-/DDN-20170919-1

Proizvodstvo svininyi za rubezhom. Retrieved from https://studbooks.net/831510/agropromyshlennost/p roizvodstvo svininy rubezhom (in Russian).

Ratsion dlia vidluchentsiv: alternatyvy oksydu tsynku. Retrieved from http://pigua.info/uk/post/technologies/racion-dlavidlucenciv-alternativi-oksidu-cinku (in Ukrainian).

Rybalko, V. (2010). Svynarstvo - natsionalna haluz. Propozytsiia. Retrieved from https://propozitsiya.com/ua/svinarstvo-nacionalnagaluz (in Ukraine).

Sudakov, M.O., Bereza, B.I.,.Pohurskyi, I.H et al. (1991). Mikroelementozy silskohospodarskykh tvaryn. Kyiv: Urozhai (in Ukrainian).

Swine Respiratory Disease (SRD). (2019). Retrieved from https://www.zoetisus.com/conditions/pork/swinerespiratory-disease- srd aspx.

The best start for piglets. Retrieved from https://www.pigprogress.net/Breeding/ PigletFeeding/2011/12/The-best-start-for-pigletsPP008135W. 